\title{
The Effect of Critical Reading Strategies on EFL Learners' Recall and Retention of Collocations
}

\author{
Amir Reza NematTabrizi \\ Payame Noor University, Iran \\ E-mail: arnemati@pnu.ac.ir \\ Mehrnoush Akhavan Saber (Corresponding Author) \\ Payam E Noor University, Iran \\ E-mail: mehr1077@gmail.com
}

Received: 12-09- 2016

doi:10.7575/aiac.ijels.v.4n.4p.30
Accepted: 13-10-2016

URL: http://dx.doi.org/10.7575/aiac.ijels.v.4n.4p.30
Published: 31-10-2016

\begin{abstract}
The study was an attempt to measure the effect of critical reading strategies, namely; re-reading, questioning and annotating on recall and retention of collocations by intermediate Iranian EFL learners. To this end, Nelson proficiency test was administered to ninety $(\mathrm{n}=90)$ Iranian EFL learners studying at Zaban Sara language institute in Esfahan, Iran. Sixty $(n=60)$ language learners were selected based on their scores on Nelson test. A pretest of collocation was administered to these participants to homogenize them based on their knowledge of collocations. Next, the participants were divided into two groups as the control group and the experimental group. While the participants in the experimental group were taught how to use critical reading strategies prior to answering the reading comprehension questions, the participants in the control group were simply asked to read the text and answer the reading comprehension questions. Both groups took a researcher-made collocation test as the test of recall (after the treatment) and the test of retention (after a 2-week interval). The findings of the study through independent samples t-test revealed that teaching critical reading strategies has a positive effect on both recall and retention of collocations. The findings of the study could be used by language teachers who aim at more effective understanding of collocations in their classes.
\end{abstract}

Keywords: Critical Reading, Recall, Retention, Collocations, EFL Learners

\section{Introduction}

The concept of collocation refers to how words occur together either in speech or writing (Kennedy, 2013). Without proper knowledge of collocations it would be impossible to speak fluently. In fact, to be able to utter native-like utterances, students need to know have knowledge of collocations (Ann, 2014). As a result, understanding collocations is an important issue in EFL/ESL settings. Although patterns of collocations are recognizable to native speakers of a language in a simple glimpse, EFL learners may have difficulty comprehending them if such concepts have not been exposed to them previously (Lewis, 2000). As a result many language researchers have investigated the effect of different teaching strategies on learning collocations (e.g., Kennedy, 2013; Lewis, 2000; Nesselhauf, 2003).

Not only is learning collocations an important issue, but also students' recall and retention of newly learned materials plays a significant role in choosing the type of strategy to learn the new language. According to Yu-Ling (2005), the main concern of EFL learners, with regard to vocabulary learning, has been recalling and retaining the newly learned vocabulary. Indeed, when EFL learners start to read a text, what comes to their minds is how to learn and recall the new vocabulary. Based on Naghizadeh and Darabi (2015), it seems that, for example in Iran, in order to learn new vocabularies, most EFL learners memorize words with their meanings by repeating them several times. However, such vocabularies may not retain in the mind. This problem may stem from lack of teaching vocabulary strategies in EFL classes. For sure, there are some learners that use some strategies unconsciously. However, lack of knowledge about these strategies has hindered their vocabulary learning and reading comprehension.

One of the strategies that could possibly enhance EFL learners' understanding about collocations is critical reading. Lewis (2000) defined critical reading as an analytic activity which requires the readers to reread a text. The reason the text is read multiple times is to understand patterns of elements, information, values, assumptions, and language usage throughout the discussion.

Critical reading involves bringing outside knowledge and values to evaluate the presentation of the text and to decide what to ultimately accept as true. There are several theory-like opinions to teach critical reading but as a whole it can be as outlined by Salisbury university website (2013):

- Previewing: Learning about a text before really reading it; 
- Contextualizing: knowing about the historical and cultural context of the text;

- Questioning: Asking questions about the content to understand and remember;

- Reflecting on challenges to find out if they match the belief and values of the readers;

- $\quad$ Outlining and summarizing: paraphrasing ideas in readers own words;

- Evaluating an argument: testing the credibility of the argument; and

- Comparing and contrasting related readings: done to find similarities and differences between the texts.

This study aimed at finding out if critical reading strategies, as outlined above, had any positive effect on recall and retention of collocations by Iranian EFL learners at intermediate level.

1.1 Statement of the Problem

As posited by Motallebzadeh, Beh-Afarin and Rad (2011) in the EFL context of Iran inadequate attention has been paid to learning collocations, as many teachers avoid teaching collocations as their own knowledge about collocations is limited. As most EFL instructors in Iran are non-native speakers of the language, they cannot provide their students with a plethora of examples on collocations. Consequently, lack of exposure to collocations reduces EFL learners' chances of learning the collocations (Ann, 2014). In most educational settings in Iran, no specific class-time is allotted to teaching collocations. Rather, students are taught the vocabulary presented in the text books. In addition, previous research on recall and retention of collocations is scant and most research in this area has its focus on vocabulary learning in general. Finally, although the effect of teaching critical reading strategy on vocabulary retention in the context of Iran has been the subject of research in some studies (Khabiri \& Pakzad, 2012) prior research has not dealt with the effect of teaching critical reading strategies on recall and retention of collocations by Iranian EFL learners.

\subsection{Research Questions}

To survey the problem mentioned in this research, the following questions were formulated:

1. Does critical reading have any effect on EFL learners' recall of collocations?

2. Does critical reading have any effect on EFL learners' retention of collocations?

\subsection{Null Hypotheses}

Based on the questions above, the following research hypotheses were formulated.

$\mathrm{H}_{01}$ : Critical reading does not have any effect on EFL learners' recall of collocations.

$\mathrm{H}_{02}$ : Critical reading does not have any effect on EFL learners' retention of collocations.

1.4 Significance of the Study

The findings of this study can be used by language teachers to make language learners aware of the critical reading strategies. This could in turn increase their ability to learn collocations effectively. In addition, the effect of critical reading strategies on recall or retention of collocations which was measured in this study could help language learners to bear the meaning of collocations for a longer duration of time in mind and also to use collocations more adroitly. Finally, this study can lead to new research areas with regard to critical reading strategies. The positive effect of critical reading strategies on recall and retention of collocations can open the gate for new scholars and language researchers to investigate the effect of critical reading strategies on other areas of English language.

\section{Review of the Related Literature}

\subsection{Theoretical Background}

Critical reading as the main independent variable in this study is defined following McDonald (2004), who described it as an alternative way of reading which is different from other approaches to reading such as information processing or personal response and goes beyond them. Critical reading is to read a text not only reflectively (Kurland, 2000) but also in a skeptical and analytical way and then to judge the value of the text (Goldman \& Wiley, 2002). According to Jones (2002), critical reading not only empowers students in EFL learning skills such as vocabulary and reading, but also helps them comprehend the text and to view the text with a critical view.

In the literature related to reading, reading seems to be of two types. According to Burns, Roe, and Ross (1999), the first type, i.e., literal comprehension is to consider directly stated ideas. It is the most basic type of reading. Critical reading, however, is different and refers to higher-order reading comprehension which goes beyond literal understanding of a text. As a result, higher-order thinking processes are involved in critical reading.

Farrokh (2012, p.55) defines learning collocations as "One of the most problematic areas for foreign language learning ... [which] is often seen as arbitrary and overwhelming, a seemingly insurmountable obstacle to the attainment of native like fluency". Generally, teaching vocabulary, with regard to the instruction of collocation, has not been emphasized adequately. However, there are some general principles for teaching collocation as stated by Richards and Schmitt (2010).

The first approach is to teach students the term "collocation" and the reason why they should learn it. Once they know the reason behind instruction, they become more eager and motivated to learn. In addition, language learners ought to notice which words go together when giving out a new reading. This should be highlighted by the help of the teachers. 
Indeed, they should ask the learners to underline any collocation they find in the text. On any given page, for example, there is likely to be numerous collocations. Thus, language learners should spend some time practicing and interacting with these collocations with each reading.

Ann (2014) posited that the salient language ought to be emphasized as well as it is often used in the curriculum. For example, the phrase "make the bed" is sometimes confused with the phrase "do the bed". Other suggestions were made to language teachers who taught collocations with regard to similar occasions such as "in the other hand" which is at times used wrongly instead of "on the other hand".

Shih (2005) suggested that students should prepare a list of collocations and practice them. The reason for this exercise is that it can give the students constant exposure to collocations. Other types of exercises were also emphasized by Shih (2005). The exercises include matching exercises, completion exercises, and surveying students. Shih (2000) expressed the problems that occur while learning collocations as those related to synonyms, avoidance, paraphrasing and transfer. Other researchers such as Sinclair (1991) believed that a suitable way to use collocations is to reveal the discoursal representations of the text as they should a semantic analysis of the words. In this way, meanings are transferred and messages are understood (Hunston, 2002).

\subsection{Empirical Background}

Although numerous studies have dealt with the issue of vocabulary learning, fewer studies have investigated the effect of reading strategies on vocabulary learning. However, one of the strategies which has raised many discussions, is acquiring vocabulary through reading.

Reading is claimed by some scholars to be the major source of vocabulary growth in both L1 and L2 (e.g. Krashen, 1989; Swanborn, 1999). In this regard, Pulido (2004) asserted that there is robust relationship between incidental vocabulary learning and text comprehension.

The findings of the study by Khabiri and Pakzad (2012) revealed that critical reading strategy is an effective approach to learn vocabulary, especially in terms of retention. Their study was carried out using 114 intermediate adult EFL learners aged between 17 to 32 in the province of Tehran. The participants were asked to take the Preliminary English Test (PET) and a researcher-made vocabulary test as the homogeneity test and the pretest respectively. Through 19 session of treatment, 8 reading comprehension texts were taught to the participants. In the experimental group, the participants were taught critical reading strategies where as in the control group the comprehension approach toward reading was used. The comparison between the pretest scores and the posttest scores proved that critical reading strategies could have a positive effect on reading comprehension of Iranian EFL learners.

In a different study, Talebi and Marzban (2015) investigated the effect of teaching critical reading strategies on retention of vocabulary items by adult EFL learners. They concluded that over two-week interval between the treatment and the retention test, no particular, change had occurred in vocabulary knowledge of the participants as teaching critical reading strategies is an effective approach to learning vocabulary. 48 advanced EFL learners were selected for their study out of 98 EFL learners by taking the paper-based TOEFL test in Sari, Iran. The participants were considered as advanced learners. Next, 5 reading texts from Critical Reading Workbook for the SAT and supplementary material from IELTS Cambridge series were practiced with the students.

Grabe (2004) asserted that there is a meaningful relationship between reading strategies used by language learners and their vocabulary knowledge. Hilton and Hyder (1995) also posited that target language vocabulary contributes to reading comprehension of EFL learners. Thus, the relationship between vocabulary knowledge and reading comprehension is mutual. Moreover, Daskalovska (2011) investigated the effect on reading on 3 aspects of word knowledge: spelling, meaning, collocations. She concluded that reading short stories could have a positive effect in all the aforementioned 3 aspects of words at intermediate level. In her study, however, the participants went mostly through extensive reading.

Min (2008) compared the effect of two different types of reading on vocabulary learning and retention of secondary school language learners. These two types of reading included 'narrow reading' and 'reading plus vocabulary enhancement activities'. These approaches to reading required repeated reading of thematically- organized articles. The results of the study revealed significant difference between the groups as the learners who read with the focus on vocabulary (reading plus vocabulary enhancement activities) outperformed the other group.

Adopting a different perspective, Prince (1996) maintains that reading develops the context for vocabulary recognition and learning and asserts that, "context provides the means to identify the meaning of the new word and not necessarily the means to learn it" (p. 489). He posited that practical reading strategies such as anticipating or making inferences which, in turn, lead to self-awareness and reliance are the outcome of learning vocabulary by reading.

Fathi (2004) delved into the effect of critical reading strategies on EFL learners' vocabulary learning. To this end, he used eighty three $(n=83)$ learners and checked their retention of newly learned vocabulary after applying critical reading strategies. He found out that critical reading strategies can enhance vocabulary learning among language learners, however, a step by step procedure to implement critical reading strategies was not conducted in his study.

However, research on the direct effect of critical reading strategies on collocations' recall and retention seems to be scarce as the researcher of the current study was not able to spot any study with such a focus. 


\section{Method}

The study is a true experimental one. In order to gauge the effect of critical reading strategies on recall and retention of collocations, the researchers made use of a control group and an experimental group. The independent variable in the study was critical reading strategies and the dependent variable was learning collocations. It should also be mentioned that, inferential statistics through independent samples t-test was used to analyze the data.

\subsection{Participants}

The participants were selected using randomized sampling method. In order to select the participants for this study, Nelson proficiency test was administered to 90 intermediate EFL learners studying at Zaban Sara Language Institute in Esfahan, Iran. As the distribution of the scores was normal (Table 1), and by considering 1SD above and below the mean score, 60 language learners were chosen as the participants for the study. Next, the participants were given a researcher-made collocation test to be homogenized based on their knowledge of collocations. The participants formed two different groups, (a) control group and (b) experimental group with 30 participants in each. The table below reveals the demographic data of the participants.

Table 1. Participants' Demographic Data

\begin{tabular}{lllcc}
\hline Group & $\mathrm{N}$ & Age & Gender & Proficiency Level \\
\hline Control & 30 & Adult & Mixed & Intermediate \\
\hline Experimental & 30 & Adult & Mixed & Intermediate \\
\hline
\end{tabular}

\subsection{Instruments}

\subsubsection{Proficiency Test (NELSON)}

Nelson proficiency test is a test often used to homogenize language learners based on their proficiency in English. The test includes 50 items. Nelson is a valid and reliable test (Shahivand \& Pazhakh, 2012).

\subsubsection{Researcher-Made Collocation Test I}

A researcher-made collocation test based on the collocations intended for this study was designed by the researcher to be used as the pretest and the posttest in this study to find out about the effect of using critical reading strategies on recall of collocations. The test consists of 30 items and was piloted prior to the main study. Item analysis was run to make check the item discrimination (ID) and item facility (IF) of the test items. The reliability of the researcher-made test was gauged using Cronbach alpha. The results of the test $(\alpha=.789)$ proved that the test had adequate reliability.

\subsection{Procedure}

Having been selected, the participants of this study $(n=60)$ formed two groups of 30 learners as the control group and the experimental group. Through 10 sessions of working on EFL learners' knowledge of collocations in the control group, no particular critical reading strategies were used. The participants went through comprehension-based approach to reading. They were given reading texts from the book, Developing Reading Skills by Grellet (1981) and were asked to answer the reading comprehension questions. In the experimental group, the participants were first familiarized with critical reading strategies. These strategies included previewing and contextualizing. The intention of previewing was to give the participants a sense of what the text was going to be about. Decontextualizing was also used to help participants define words in light of their experience. Next, the participants were asked to use the strategies to read texts which contained collocations. Then, the participants were asked to re-read the text and try to make connections between the text and the outside world. They were asked to question the concepts presented in the reading text and try to find inferences in the text to answer their questions. The process was monitored by the classroom teacher and lasted for 10 sessions both in the control group and the experimental group. One day after the treatment course was over; the participants received a piloted version of the researcher-made test on collocations to investigate the extent to which they could recall the newly learned collocations. In the same vein and after two weeks, the same test was administered to the participant to investigate participants' ability to retain collocations.

\subsection{Data Analysis}

In order to run the analysis and considering that quantitative data analysis was required to answer the research questions, SPSS (version 22) was used as the main software. The assumption of normal distribution was checked by using ratios of skewness and kurtosis. Homogeneous groups were formed using independent samples t-test and posttest results of the groups was compared using the same tool.

\section{Results}

\subsection{Exploratory Data Analysis}

The distributions of the participants' scores on both pretest and posttest were checked for their normality. Since the values of skewness and kurtosis ranged between \pm 1 , the assumption of normality was met, meaning that t-test could be used for testing the statistical significance of the difference between the two groups' mean scores. 
Sixty participants $(n=60)$ were chosen out of 90 EFL learners by considering 1 standard deviation above and below the mean score of the participants. These participants formed two groups for the study (the control group and the experimental group). After the pretest, independent samples t-test was run to make sure the two groups were of no statistical difference based on their knowledge of collocations before the treatment.

Table 2. Mean Scores by Groups

\begin{tabular}{lllll}
\hline Groups & $\mathrm{N}$ & Mean & Std. Deviation & Std. Error Mean \\
\hline Control & 30 & 28.7000 & 3.05298 & .55740 \\
Experimental & 30 & 28.6333 & 3.13471 & .57232 \\
\hline
\end{tabular}

As displayed in Table 2, the control group $(\mathrm{M}=28.70, \mathrm{SD}=3.05)$ had a slightly higher mean than the experimental group $(\mathrm{M}=28.633, \mathrm{SD}=3.134)$ on the homogeneity test.

Table 3. Mean comparison between the control group and the experimental group

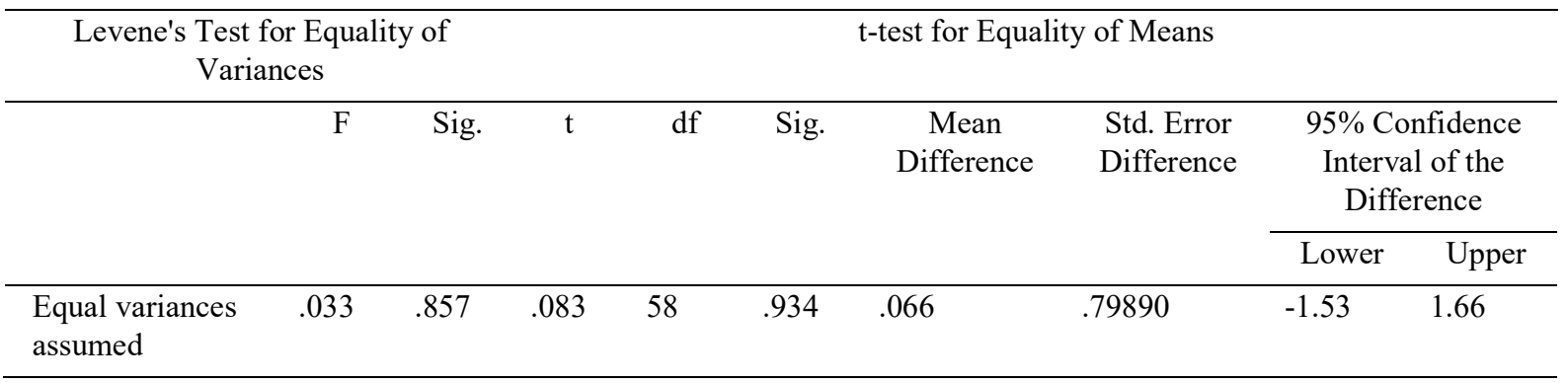

However, based on the independent samples t-test results (Table 3$),(\mathrm{t}(58)=.934, \mathrm{p}=.066)$ the difference was insignificant. Thus, it can be claimed that the two groups were homogenous in terms of their proficiency level prior to the main study.

\subsection{Effect of critical reading on learners' recall of collocations}

Independent samples t-test was run to compare the two groups' posttest results and to answer the first research question 'Does critical reading have any effect on EFL learners' recall of collocations?'.

Table 4. Descriptive statistics results of the two groups' posttests

\begin{tabular}{lllll}
\hline Groups & $\mathrm{N}$ & Mean & $\begin{array}{l}\text { Std. } \\
\text { Deviation }\end{array}$ & $\begin{array}{l}\text { Std. Error } \\
\text { Mean }\end{array}$ \\
\hline Control & 30 & 16.9667 & 2.79758 & .51077 \\
\hline Experimental & 30 & 22.0000 & 2.71649 & .49596 \\
\hline
\end{tabular}

As can be seen in Table 4, the mean score of the control group participants $(M=16.966, S D=2.79)$ is considerably lower than the mean score of the experimental group $(\mathrm{M}=22, \mathrm{SD}=2.71)$.

Table 5. Independent samples t-test results to compare learners' recall of collocations scores

\begin{tabular}{|c|c|c|c|c|c|c|c|c|c|}
\hline \multicolumn{3}{|c|}{$\begin{array}{c}\text { Levene's Test for Equality of } \\
\text { Variances }\end{array}$} & \multicolumn{7}{|c|}{ t-test for Equality of Means } \\
\hline & \multirow[t]{2}{*}{$\mathrm{F}$} & \multirow[t]{2}{*}{ Sig. } & \multirow[t]{2}{*}{$\mathrm{t}$} & \multirow[t]{2}{*}{$\mathrm{df}$} & \multirow[t]{2}{*}{ Sig. } & \multirow[t]{2}{*}{$\begin{array}{c}\text { Mean } \\
\text { Difference }\end{array}$} & \multirow[t]{2}{*}{$\begin{array}{l}\text { Std. Error } \\
\text { Difference }\end{array}$} & \multicolumn{2}{|c|}{$\begin{array}{c}95 \% \text { Confidence } \\
\text { Interval of the } \\
\text { Difference }\end{array}$} \\
\hline & & & & & & & & Lower & Upper \\
\hline $\begin{array}{l}\text { Equal variances } \\
\text { assumed }\end{array}$ & .127 & .723 & -7.07 & 58 & .000 & -5.033 & .711 & -6.458 & -3.608 \\
\hline
\end{tabular}


As shown in Table 5, the results of independent samples t-test $(\mathrm{t}(58)=7.07, \mathrm{p}=.000)$ show a significant difference between the scores of the control group and the experimental group. Therefore, the first null hypothesis is rejected.

\subsection{Effect of critical reading on learners' retention of collocations}

The second research question was 'Does critical reading have any effect on EFL learners' retention of collocations?' In order to probe the answer to the second research question, the experimental group's scores on the posttest (recall test) and delayed posttest were compared using paired samples t-test (Table 6).

Table 6. Paired samples t-test results

\begin{tabular}{|c|c|c|c|c|c|c|c|c|}
\hline \multirow[t]{2}{*}{ Pairs } & \multirow[t]{2}{*}{$\mathrm{M}$} & \multirow[t]{2}{*}{ SD } & \multirow{2}{*}{$\begin{array}{l}\text { Std. } \\
\text { Error } \\
\text { Mean }\end{array}$} & \multicolumn{2}{|c|}{$\begin{array}{l}95 \% \text { Confidence Interval } \\
\text { of the Difference }\end{array}$} & \multirow[t]{2}{*}{$\mathrm{t}$} & \multirow[t]{2}{*}{ Df } & \multirow[t]{2}{*}{ Sig. } \\
\hline & & & & Lower & Upper & & & \\
\hline Posttest & 22.00 & 7.234 & 4.176 & -3.968 & 5.968 & .866 & 29 & .478 \\
\hline Delayed posttest & 20.68 & 5.507 & 3.179 & & & & & \\
\hline
\end{tabular}

As can be seen in Table 6, the mean difference between the two tests is small. In addition, the results gained from the paired samples t-test, $(\mathrm{t}(29)=.866$, Sig=.478) reveal that the difference between the two groups was not statistically significant. Therefore, the second null hypothesis is also rejected.

\section{Discussion}

The study revealed that critical reading could be an effective strategy for learning collocations. In addition, it was proved that, critical reading could have a positive effect on both recall and retention of collocations. The following paragraphs try to expand on other studies carried out so far to measure the effect of critical reading strategies on learning collocations. However, most studies conducted have investigated the effect of critical reading on learning vocabulary and not learning collocations specifically.

The findings of the study by Khabiri and Pakzad (2012) revealed that critical reading strategy is an effective approach to learn vocabulary, especially in terms of retention. Their study was carried out using intermediate adult EFL learners and is very similar to the current study except for the fact that this study deals with learning collocations. In a similar study, Talebi and Marzban (2015) investigated the effect of teaching critical reading strategies on retention of vocabulary items by adult EFL learners. They concluded that over two-week interval between the treatment and the retention test, no particular, change had occurred in vocabulary knowledge of the participants.

Grabe (2004) asserted that there is a meaningful relationship between reading strategies used by language learners and their vocabulary knowledge. Hilton and Hyder (1995) also posited that target language vocabulary contributes to reading comprehension of EFL learners. Thus, the relationship between vocabulary knowledge and reading comprehension is mutual. Considering that collocations are combination of vocabulary items, it can be stated that the findings of the current study are congruent with the findings of Grabe (2004) and, Hilton and Hyder (1995).

Daskalovska (2011) investigated the effect on reading on 3 aspect of word knowledge: spelling, meaning, collocations. She concluded that reading short stories could have a positive effect in all the aforementioned 3 aspects of words at intermediate level. The difference between the study carried out by Daskalovska (2011) and the current study in terms of procedure was that her participants went mostly through extensive reading, whereas as the participants in this study were asked to reread the texts and question the meaning of the text. However, in line with Daskalovska (2011) and previously mentioned studies in the discussion section, reading could have a positive effect on learning vocabulary. The last example, in particular, mentioned the effect of reading on learning collocations.

\section{Conclusion}

The study was an attempt to investigate the effect of teaching critical reading strategies on learning collocations by Iranian EFL learners at intermediate level. The focus of the study was on recall and retention of collocations. The results of the study proved that critical reading strategies can significantly affect learning collocations by EFL learners not only in terms of recalling the collocations but also in terms of retention of collocations. The findings of this study could be used by EFL teachers who intend to teach collocations to their language learners through critical reading strategies, and language learners who intend to have a more comprehensive knowledge of collocations. Material developers, on the other hand, can prepare reading materials in a way that makes learning collocations more convenient. One way to do so is to deliberately use collocations in the reading texts. 
References

Ann, S. (2014). 10 tips to teach collocations. Retrieved from www.busyteacher.org

Burns, P. C., Roe, B. D., \& Ross, E. P. (1999). Teaching reading in today's elementary schools (7th Ed.). Boston: Houghton Mifflin.

Collocation strategies (2014). How-to-teach-collocations. Retrieved from http://elthq.com/how-to-teach-collocations/

Crow, J. T. (1986). Receptive vocabulary acquisition for reading comprehension. The Modern Language Journal, 70 , $242-250$.

Daskalovska, N. (2011). The impact of reading on three aspects of word knowledge: spelling, meaning and collocation. Procedia-Social and Behavioral Sciences, 15, 2334-2341.

Fathi, M. (2004).The effect of reading strategies on vocabulary retention. (Unpublished master's thesis). Tehran, Iran.

Goldman, S. R., \& Wiley, J. (2002). Scientific literacy: The centrality of critical reading. Paper presented at the international Conference Ontological in Canada.

Grellet, F. (1981). Developing reading skills: A practical guide to reading comprehension exercises. UK: Cambridge University Press.

Hunston, S. (2002). Corpora in applied linguistics. Cambridge: Cambridge University Press.

Jones, L. (2002). A critical review of media studies advocacy and its underlying assumptions and agendas. EFL Journals, 59(3), 219-231.

Kennedy, G. (2012). Amplifier collocations in the British national corpus: Implications for English language teaching. DOI: $10.2307 / 3588400$

Khabiri, M., \& Pakzad, M. (2012). The effect of teaching critical reading strategies on EFL learners' vocabulary retention. Journal of Teaching Language Skills, 4(1), 73-106.

Krashen, S. D. (1989). We acquire vocabulary and spelling by reading: Additional evidence for the input hypothesis. The Modern Language Journal, 73, 440-464.

Kurland, D. J. (2000).What is critical reading? Retrieved December 26, 2009, from http://www.criticalreading.com/critical_reading.htm

Lewis, M. (2000). Teaching collocation: Further developments in the lexical approach. Hove, England: Language Teaching Publications ISBN 1-899396-11-X

McDonald, L. (2004). Moving from reader response to critical reading: Developing 10-11-year-olds' ability as analytical readers of literary texts. Literacy, 38(1), 17-25 DOI: 10.1111/j.0034-0472.2004.03801004.X

Min, H. (2008).Reading plus vocabulary enhancement activities and narrow reading. Language Learning, 58(1), 73115.

Motallebzadeh, K., Beh-Afarin, R., \& Rad, S. D. (2011). The Effect of short message service on the retention of collocations among Iranian lower intermediate EFL learners. Theory and Practice in Language Studies, 1(11), 15141520 .

Naghizadeh, M., \& Darabi, T. (2015). The Impact of Bimodal, Persian and No-Subtitle Movies on Iranian EFL Learners' L2 Vocabulary Learning. Journal of Applied Linguistics and Language Research, 2(2), 66-79.

Nesselhauf, N. (2003). The use of collocations by advanced learners of English and some implications for teaching. Oxford Journals Arts \& Humanities Applied Linguistics, 24(2), 223-242

Prince, P. (1996). Second language vocabulary learning: The role of context versus translations as a function of proficiency. The Modern Language Journal, 80, 478-493.

Pulido, D. (2004). The relationship between text comprehension and second language incidental vocabulary acquisition: A matter of topic familiarity? Language Learning, 54(3), 469-523.

Richards, J., \& Schmidt, R. (2010). Dictionary of language teaching \& applied linguistics (4th Ed.). Great Britain: Longman.

Salisbury University (2013). 7 critical reading strategies. Retrieved from http://www.salisbury.edu

Stevens, J. P. (2009). Applied Multivariate Statistics for Social Sciences. (5 ${ }^{\text {th }}$ ed.). NY: Routledge.

Shahivand, Z., \&Pazhakh, A. (2012). The effects of test facets on the construct validity of the tests in Iranian EFL students. Higher Education of Social Science, 2(1), 16-20.

Shih, R. H. (2000). Collocation deficiency in a learner corpus of English: From an overuse perspective. Research conducted from National Sun Yat-sen University, Kaohsiung, Taiwan.

Sinclair, J. Mc H. (1991). Corpus concordance collocation. Oxford: Oxford University Press.

Swanborn, M. S. L. (1999). Incidental word learning while reading: A meta-analysis. Review of Educational Research, 69(3), 261-286. 
Talebi, M., \& Marzban, A. (2015). The Effect of Teaching Critical Reading Strategies on Advanced Iranian EFL Learners' Vocabulary Retention. Theory and Practice in Language Studies, 5(3), 572.

The free dictionary (2014). Retrieved from http://www.thefreedictionary.com

The Importance of Learning Collocations instead of Individual Words (n.d). Retrieved from www.Ielanguages.com. Yu-Ling, L. (2005). Teaching vocabulary learning strategies: Awareness, beliefs and practices. A survey of Taiwanese EFL senior high school teachers (Unpublished Dissertation MA). University of Essex: Essex. 